\title{
Benchmarking Innovation: Comparison of Industrial's SMEs in Argentine and France
}

\author{
Rodríguez Rey J. ${ }^{1}$, Galvez D. ${ }^{1}$, Morel L..${ }^{1}$, Camargo M. ${ }^{1}$, Boly V. ${ }^{1,}$ Forradellas R ${ }^{2}$. \\ ${ }^{1}$ Equipe de Recherche sur les Processus Innovatifs, \\ ERPI ENSGSI, 08 rue Bastien Lepage-BP 647, 54010 Nancy Cedex, France \\ ${ }^{2}$ CEAL - Logistics Studies and Application Centre,School of Engineering, Universidad Nacional de \\ Cuyo, Argentina. Centro Universitario (M5502KFA), Mendoza.
}

\section{ABSTRACT}

Benchmarking has become a useful tool for companies for decision-making and improvement of internal practices. Nevertheless, in innovation capabilities, benchmarking applications have been scarce. This study's main objective was to perform a comparative analysis of the innovation potential of two groups of companies belonging to Argentine and France. Besides the potential for innovation, components of this potential were compared finding strengths and weaknesses of both groups. To do that, the methodology of Innovation Potential Index (IPI) has been used. Through a survey based on acceptance grids, collection of the particularities of both groups has been made. By means of statistical analysis the main differences and similarities have been clarified. Among the most important findings are the similarities between the groups in the classification: in both samples, $60 \%$ of cases had a low potential for innovation (passive and reactive categories). Significant differences were found in terms of innovation strategy where French companies performed better than the argentine ones. About innovation project management, Argentinian firms perform better. Human resource results barely developed in the entire sample. The similarities, due to the fact of belong to SME category, results clearly evident. Also differences in some characteristics closely related to markedly different macroeconomic environment have emerged.
General Terms Innovation management

Indexing terms Innovation capability Benchmarking - Industrial SME management Argentine-France SME - Innovation Potential Index

\section{Academic Discipline \& Sub- Disciplines Industrial engineering}

Subject Classification E.g., Mathematics Subject Classification; Library of Congress Classification

Coverage Argentina - France

\section{Type (Method/Approach)}

Benchmarking - Innovation Potential Performance measurement systems

\section{INTRODUCTION}

It is a fact that innovation drives the firms to a superior competitive level. In the long run, it is technological innovation capability that forms a major source of competitive advantage. (1) Innovation allows firms to access to specialty markets where competence is not strong and benefits are important (2). This last fact is especially important to SME dynamics. According to (3), the firms must innovate in a way that they call "Value Innovation" to achieve high and sustainable growth.

Indicators to measure innovation such as patents, number of new products launched to market and other similar based in results have the disadvantage of separate in time the causes of its 
effects. It makes that manage innovation by media of these indicators be complicated and frequently deficient. In addition, and according to (4), the number of innovations is not a reliable indicator for innovation performance due significant differences across industries. A firm's competitive advantage could come from the efficiency and capability of new product developments (1). Instead, the measurement of innovation potential presents an improvement in this sense by allowing visualizing the actual firm present situation.

To achieve that, it is very important to know the references values of the measurement in the firm, compared with other firms or other markets with a different development. To compare, benchmarking methodologies can be used. It can work over the whole indicator of innovation or by observing its components. These results are particularly useful when the firm must compare itself with firms in same sector and firms belonging to other sectors.

Nevertheless, in innovation practices, benchmarking applications have been scarce. In part, this lack can be explained by the difficulty to measure innovation capability by mean of innovation practices, as those metrics correspond to the intangible actives of the companies (5). Measuring innovation level of an enterprise is a complicated and difficult task due to the complexity of the processes and the difficulty of establishing the variables to be measured. (6).

Innovation has been described as "the engine that drives revenue growth" (7). (8) considered benchmarking as the basis for organizational survival. So there is a need to understand the mechanisms driven the innovation process in order to manage it, and then support a continuous growth of the companies. However, this is a complex process depending on several factors and strongly influenced by context and sectorial features. These last years, a body of knowledge has been developed on the understanding of the innovation drivers and metrics (9) (10) (11) (12). Firms are prone to benchmark their reality versus other firms about several performance measures, innovation performance included (8).

Benchmarking for best practices was first implemented by Xerox in 1979 and has been applied in almost all operational and managerial areas by numerous researchers (13). The process of Benchmarking implies improving performance by continuously identifying, understanding (studying and analyzing), and adapting outstanding practices and process found inside and outside the organization and implementing the results (14). Today benchmarking is wide used as decision making tool in areas such as supply chain (15); manufacturing, commerce and in innovation field (8), (13), (14).

To explore the relationship between technological innovation capability and competitiveness, (1) have used the multi-objective DEA projection model to benchmark competitiveness in a set of electrical manufacturing firms in China. To determinate the relationship between strategic alignment and business performance, (15) have developed a model and applied it to electronic industry, determining the innovation profile of the sample. In Finland, (13) have used benchmarking to compare the performance of the buyer-suppliers relationship in high tech industry.

Recent years many studies have attempted to answer this need to measure innovation capacity (11) (16) (12) ( (6), (17). The evolution of innovation metrics aimed at measuring innovation in relation to the processes and practices involved in it (2). Within this framework is the methodology proposed by (18), who defines the calculation of a Innovation Potential Index IIP based on multi-criteria evaluation of six main criteria to evaluate the innovation capabilities within companies (creativity, conception activities, Human resources management, strategy, project management and knowledge management). According to their IPI the companies can be classified into 4 categories (Proactive, Preactive, Reactive, Passive) by means of the classification proposed by (19) to explain the strategic vision of a company on its market.

This method is selected due the advantages that presents compared with the flux methods (measurement of innovation results, like patents and new products). A broad part of the sample belongs to low-tech SME's and there is a marked informality in innovation process. It is very frequent that firms have not patents registration at all. Otherwise, like occurs in construction sector firms, a personalized production is made and the 
concept of "new product" may be difficult to measure. It can be confused with incremental innovation concept. Most of measured practices belongs to the non-R\&D issues (20).

Among the main results, similarity was found about the low level of innovation in the samples. In both countries, over $55 \%$ of the companies studied were evaluated within the lowest innovative category (Passive). By contrast, the biggest differences appear in the "Strategy" and "Project management" criteria. In the first one, French companies perform better that Argentinian, while in the second one, the opposite occurs. All the firms in the sample perform less than $50 \%$ of its maximum potential value in almost every criterion. All the differences found have a strong relationship with the firm's environment and operating sector. The distribution of firms about innovation class was similar in both panels.

The fact to belong to SME category implies significant similitudes in innovation management in the two samples. A wider dispersion in performance in some criteria's that are accented in French firms, suggest that inter-sector differences are more important than inter-region ones. Public policies and regional economic stability allows French firms to be more strategic-thinking than Argentinians firms. Differences favoring to Argentinian sample in Design and Conception could be due the informal access to CAD software. Also favorable to Argentinian sample, the Project management criteria can be more exigent in the referred group because the $74 \%$ of the panel belongs to construction sector; particularly sensible to project management discipline. The Human resource management to innovate appears neglected in more performing firms in both panels, while this phenomenon doesn't occurs in passive class. The high proportion of firms in the lowest class confirms the difficult of SME to achieve higher performance in innovation.

\section{LITERATURE REVIEW}

\subsection{Innovation measurement in Latin America}

In a research performed by (23) they have measured the innovation capabilities of a mining SME panel in Antofagasta, Chile. By media of surveys, different aspects of the innovation process were measured, such as types of innovation, origin of innovative ideas, execution of innovation activities, technical progress in equipment purchased, innovation obstacles, financing; among others. It was found that the firms are awareness of the importance of innovation, but many obstacles to innovate are recognized. This constrains can affect negatively the project of creating an industrial and service cluster. In the same line, (24) stays that while innovation measured as inputs and results refers to flows, the evolutionary literature shows the possibility of accumulating knowledge (learning). This way, not only stocks but also flows play a decisive role in the generation of dynamic competitive advantages. These collections, usually called technological capabilities, involve aspects such as qualification of human resources skills, the "ways of organizing" and the existence of formal structures and informal research and development.

In earlier jobs (12) developed a methodology to measure the ICI (Index of innovative capabilities) is found. It consists in the aggregation of factors according to concept similitude. The main categories, used to index calculation were: Capacitating, technical people participation, quality management, networking and employees involving degree. The ICI indicator is relative to the best in class of the firm's panel in witch is applied. In this research, it was found that firms face to an increasing uncertainty that force them to propose a defensive strategy. The innovation efforts fall in a marked informality. Firm searches promoting its innovation capacity to enhance competitiveness. Results show the existence of a threshold effect regarding to human resources affected to innovation activities, firm size and technological profile that allows to the innovation capacity impacts over the firm's results. Firms with better innovation capacity have shown better results in decreasing costs and increasing profits. Majority of firm's doesn't see the link between investment and innovation capacity, losing in the complexity of innovation process. Lastly, firm's 
doesn't show an adequate knowledge of the government support programs and action in favor to increase innovation capacity in the firms.

In a work performed by an argentine foundation (21), certain behaviors on a very big panel of SMEs were surveyed: New product introduced to market, significant enhancement of an existing product, process enhancement, organizational enhancement and new manufacturing process development. No index has been developed, but a classification was done.

In Argentina, considered the cases cited early, there are not contemporary empirical evidence about the measurement of innovative capabilities in industrials SMEs. Also, It is not found evidence of comparison about panels of firms belonging to Argentina and France. In (12) are referenced results founds in Italian firms, but due to the year in which the research was conducted, it is possible that the results not be actually significant.

\subsection{Innovation management in SMEs}

New technologies and flexible production organization are acquiring increased importance on the competitiveness of firms. The emergence of new techno-organizational paradigms produces changes in production organization that have important impacts on innovative activities. Indeed, the growing importance of the factors "no price" of competitiveness (quality, service, sales, customization, design capacity, etc.), market segmentation and the shortening of life cycle products, are getting more and more important. For the development of innovative processes is becoming increasingly important networking, business cooperation and the set of interfaces that are formed between actors and institutions involved (universities, business service centers, research centers, etc.) (22).

It is wide the bibliography about the innovation process and their impact in the actual economy. In several cases, it makes reference to the relationship between innovation and firm growth. (2) points how must be introduced successfully a new product, service or process. He notes the following aspects: Success (Enterprise permanency, employment generation, profit, etc.), Utilisation by the clients, Value Generation (profit, novelty for the clients, new uses of the products, etc.), Differentiation, total or partial with existent products.

(23) states that fostering an innovation orientation has stronger effects on firm performance than creating innovation process outcomes such as patents or innovative products or services. In the same work the importance for entrepreneurs and SMEs to manage the innovation process diligently is highliteed. Innovation has a stronger impact in younger firms than in more established SMEs, so this could indicate that newness of younger firms can be considered an asset for new firms. New firms possess unique capabilities to create and appropriate value through innovations. Also they mark that internal innovation projects increase the performance compared whith projects that involve external collaborators. Another foounding from this research was that the cultural firm's operating context mpacts the innovation-performance relationship. Innovation has the strongest positive impact in cultural environments characterized by collectivism. (24) concludes that, for the growth based on the innovation in companies of the UK, the management abilities are more important than the financial factors.

The innovation is a source of profitability. (2) affirms that the innovation process managed in an appropriate way, offers the opportunity to the company of consenting to markets of superior margin in which the competition is not properly organized and it also allows the access to the specialization markets.

(23) states that due to the important role SMEs play for economic and technological development, innovation in the context of smaller firms has received much interest in literature, especially because SMEs are often successful innovators. Smaller, nimbler structures and an entrepreneurial posture promoted by founders and managers can facilitate innovation activity in SMEs. Via Innovation, entrepreneurial firm's gains rents through the temporary establishment of a monopoly that sustained in time can be the key source of long-term entrepreneurial success.

Product development process leads to competitive advantage via enhancement, recombination or creation of resources and their deployment in value-creating strategies. The ability to 
reconfigure their resource base of SMEs compared to large corporations generates dynamics capabilities to SMEs that can benefit greatly from innovation. In addition to the direct effects on SMEs' performance, learning during the innovation process generates absorptive capacity defined as the capability to identify, assimilate, and apply knowledge, generating a competitive advantage (25).

\subsection{SME Characterization}

Micro, small and medium-sized enterprises (SMEs) play a central role in the economy. They are a major source of entrepreneurial skills, innovation and employment. In the enlarged European Union of 25 countries, some 23 million SMEs provide around 75 million jobs and represent $99 \%$ of all enterprises (4). However, they are often confronted with market imperfections. SMEs frequently have difficulties in obtaining capital or credit, particularly in the early start-up phase. Their restricted resources may also reduce access to new technologies or innovation (26).

Additionally, smaller firms differ from larger firms in terms of their organizational structures, managerial styles, responses to the environment, and how they compete. SMEs must overcome size disadvantages by creating advantages in flexibility of production, speed of attack, niche strategies focusing on price and quality, and disrupting the status quo through innovation (27).

Many SMEs have some difficulties converting research and development into effective innovation. Many of these difficulties are organization specific. It is suggested that, in general, investment in $R \& D$, the number of new products introduced, the need to meet technological changes in both processes and products and the importance of prototype development are the most important attributes of innovation in manufacturing SMEs. SMEs face important challenges as they decide whether to build on their existing organizational capabilities or pursue entirely new business ventures (28).

According to (29) the SME cannot benefit of big volumes of production, economies of scale, etc. They should base their offer on the differentiation, much more than the big companies. Most of the SMEs run in an environment of informality. (30) States that the SMEs face high degree of financial problems and the typical tools of strategic analysis are not pertinent. The SMEs should think before in surviving rather than grow, so the fight is centered about the vulnerability factors. It is better the SMEs don't face openly to the competition, but rather they look for a niche strategy. SMEs have a necessity of constantly contrast its strategic ambitions against its financial possibilities.

Smaller and especially new firms often lack this organizational capability and, thus, experience running the risk of engaging in managerial undertakings without experience. Reflecting on the perils of innovation, it needs to be noted that innovation is a task fraught with high failure rates or at least temporary unprofitability (23).

By (4) Small manufacturing firms are almost as innovative as large firms. Additionally, SMEs also conduct a growing share of R\&D. SMEs, however, are reported to face a number of impediments to their growth and survival including limited access to financing, limited market power, the lack of management skills, high share of intangible assets, deficient accounting track and insufficient assets (31). The scenario of business in that it operates an SME is conditioned by a group of factors, among those that stand out the regulatory frameworks, the rules and political macroeconomic, the industrial strategy and politics, the access to the markets, the degree of complexity of the productive network and the technological and organizational characteristics of the leaders companies in the sector.

SMEs suffer from a lack of resources both human and financial so becoming a part of innovative consortia allows them to share R\&D costs, but also knowledge, provides indirect opportunities for marketing through consortia partners, and also diffuses the envy, failure and blame culture that pervades European society (32).

\subsection{Argentinian SMEs}

Argentinian SMEs are mostly familiar ownership. Almost $70 \%$ meet these parameters and rise near the $85 \%$ in the small firms. The familiar characteristic impacts over several economic and 
productivity aspects such as control, expansion, innovation, etc. Most of firms aren't news in the market, they have a vast fund of knowledge. Almost $60 \%$ of the firms have a minimal age of 20 years and only $12 \%$ are newer than 12 years. The ager SMEs have been developed considerable knowledge stocks about management, technics and relates to engineering, all of them adapted to the uncertain macroeconomic always present in the environment. The newer firms are generally smaller in investment and in workforce size. They tend to be less productive and operate in the lower layer of the market, where the competitive pressure is weaker. In Argentinian SMEs converges formal knowledge and learning acquired "on the way". The education level of owners is about $60 \%$ media school and only $10 \%$ are university graduates with an important level of diversification about the specific scope of the firm. In the low tech firms, this difference accentuates. The great part of learning is achieved by doing and resolving problems. The productivity likening with other firms appears to be significant in the results. The Argentinian SMEs have a workforce of about 50 stable employees (33).

Argentinian SME have register a low level in investment in the last years and a technological path with important interruptions. About $15 \%$ of SMEs doses not register an important investment in the last 6 years. The $40 \%$ have done a medium size investment (under U\$100.000) and the rest have done investment over this amount. The average age of the equipment is about 12 years. Incorporation of new equipment has mainly the goal of cost reduction, increase quality and increase production (31).

In the Argentinian SME the management is strongly centralized and based in abilities linked to manufacturing. SME tends to diversify its offers as response to the almost constant crisis keeping a high level of horizontal integration. Argentinian SMEs are weakly linked with the regional industrial web due constants change in its offer and target markets. It is not observed in the firms the concentration strategy that allows increase knowledge via specialization. Outsourcing is utilized only faced to demand variation but not as a work division strategy (37).
SMEs are almost exclusively oriented to the internal market. Most of SME have tried to export without good results. In part, this occurs due to the administrative difficult that are present in the exportation process. Other strong reason is the existence of a pseudo-service, for example, parts treatment, etc. Argentinian SME are strong business to business oriented. Large proportion of SME does not sell its product to the final market. The other parte sell its products mostly to some external commercialization channel. Most of SMEs don't have strategies to medium time. A reduced subset considers as key success factors doing important technical-organizational changes (33).

The problems facing most competitive firms are completely different from those of concern to the lowest level of competitiveness. The most competitive have difficulty competing in international markets and to incur high costs of logistics, among others. The less competitive, however, receive strong competition in the domestic markets; have problems with decreased profit margins and increased production costs. Beyond business, differences between industrial sectors in terms of competitiveness are important. In the case of sectors that receive strong competitive pressures from imported goods, high levels of competitiveness are found (21).

\subsection{French SMEs}

From (4), it is possible to know that France demonstrates solid science and innovation performance in a number of areas, such as human resources in science and technology (HRST). It had 8.4 researchers per thousand employments in 2007. The $12.9 \%$ of firms collaborating on innovation activities is marginally above average. Patent applications with foreign co-inventors suggest strong links. Some aspects of France's innovation performance have softened in recent years. The unemployment rate increased to nearly $10 \%$. France's innovation policy is based on legislation passed in 1999 and 2003. During 2008 and 2009 the implementation of the National Research and Innovation Strategy provided an overview of the state of play in innovation. The overall aim of innovation policies is to increase 
support to business R\&D and innovation, focusing on three priorities: the strengthening of the incentives for the private sector; the setting up of synergies between key actors of the innovation process in competitive clusters; and support for competitiveness in small and medium-sized enterprises.

Particularly for the Lorraine region (34), the sector, excluding agriculture and financial sectors, have more than 78.000 firms in Lorraine. The small firms are the $80 \%$ of the total. More than $40 \%$ of them have no employees and the 35\% have one employee. The medium firms are less than $20 \%$ and the major part of them has less than 50 employees. The small firms have about $17 \%$ of the total employees and the medium enterprises about the 80\% (almost 90.000). The big enterprises employ more than 6 employees over 10. But if the not employment firms are includes, Lorraine's SME employs about $45 \%$ of total workforce.

About the sector distribution, commerce is the most frequent and then, in decreasing order: Construction, health and health service, operational service, hotel and gastronomy, etc. The most important in employee's quantity terms are: Commerce, construction, transports and metalwork.

In industry, the small firms are rarer. In the clothing, small firms manufacturing custom clothing are widely distributed. The food industry also has a large number of small firms. Bakeries and pastries are the majority. En the other hand, the industry has many SMEs. If bakeries are also well represented, facilities for general engineering, boiler-piping, printing, wood industries are also present.

\section{METHODOLOGY}

\subsection{Benchmarking}

According to (8), the comparison of operations within one organization with those in other is known as benchmarking. Xerox used 'competitive benchmarking' in 1979 to describe the process in which the manufacturing division revitalized itself by comparing the features of its assemblies and processes with those of competitors. Benchmarking is defined as a continuous search for and application of significantly better practices that lead to superior competitive performance. Benchmarking is in effect a tool which may be used to measure and improve performance.

Benchmarking, a management tool for organizational learning, has been suggested as a method to improve some capabilities. Benchmarking is the process of identifying the highest standards of excellence for products, services or processes, and then make the improvements necessary to reach those standards or "best practices". It offers the opportunity to recognize good performance and expose poor performance for remedial action. (35)

Use of benchmarking enables the organization to develop an understanding of how exceptional performance is obtained. Any benchmarking exercise should therefore result in two types of out-puts: the benchmark comparative data and a set of enablers that represent the practices that underlie the performance. Deming said in a Hewlett Packard meeting that users of benchmark data should 'Adapt, don't adopt.' Context in which the benchmark companies operate influence the process enablers. Direct transfer of practices has proved unsuccessful since companies may differ in business environment.

A number of different types of benchmarking can be found, including internal, external, noncompetitive, competitive, performance and bestpractice bench-marking. The use of competitive benchmarking can foster innovation, and enhance product and service quality (8).

(13) Bench-marking presents a systematic management process that helps managers to improve critical business processes by adopting the peak performance of the best-in-class company. Its general advantages is achieved by analyzing the operation, knowing the best of the best (BOB), incorporating the world-class performers, and gaining superiority. The benchmarking process gathers standards for improvement. As a method benchmarking allows adapt the best practices into one's own circumstances in the way most valuable for the company and its customers. Benchmarking identifies business trends, and it serves as an early detection device for problems. It can also be used to perform a competitive analysis. 
Development in the benchmarking should follow the "thinking is out of the box" approach where benchmarking results take the company closer to the world-class performance level.

(36) states "Benchmarking is emulating the best by continuously implementing change and measuring performance". "Benchmarking is the process of improving performance by continuously identifying, understanding (studying and analyzing), and adapting outstanding practices and process found inside and outside the organization and implementing the results".

These best-in-class performers set a benchmark. A benchmark is the standard of excellence against which to measure and compare. Benchmarks are performance measures: how many? How quickly? How high? How low?. Establishing benchmarks is a necessary part of benchmarking. But of itself does not provide an understanding of best practices nor does knowledge of the benchmarks lead necessarily to improvement. "Benchmarks are facts; benchmarking enables real improvement" (37). Benchmarking is actually the process of learning lessons about how best performance is accomplished. Rather than merely measuring best performance, benchmarking focuses on how to improve any given business process by exploiting 'best practices' by discovering the specific practices responsible for high performance, understanding how these practices work, an adapting and applying them to the organization.

\subsection{The Innovation Potential Index (IPI)}

Innovation potential can be defined as the continued improvement in the set of capacities and resources that firm has to explore and exploit the opportunities to develop and launch to the market new products and services (38). Firm competitiveness is based over certain complex capacities, and then, a unique performance criterion is not enough.

(39) defined the Innovation Potential Index (IPI), which is calculated using multicriteria decision tools. They have uses as bases the 13 practices of innovation engineering defined by (2). These practices are concrete actions executed by the enterprises to define their strategy, to guide and to impel the innovation processes and to make evolve the organization or its methods of work. The index will allow obtaining a classification of the enterprises, created by (19), according to the nature of its system of innovation and classifies companies as: Proactive, Preactivate, Reactive and Passive. The classification is presented:

- "Proactive" are the most dynamic and most offensive companies, these who create technological changes in a long-term vision.

- "Preactive" are companies that don't ignite the changes, but which anticipate them by the use of a very active system of technology monitoring. They are also dynamic and offensive companies but having a strategic vision with average term.

- "Reactive" are companies which react to the dynamics of their environment. This means that the only technological change drivers become from concrete demands from the market. Their vision of economic planning is short-term.

- "Passive" are companies which adopt a defensive attitude in front of disturbances of the environment, that is to say that they think only of surviving.

Based on this work, (40) propose a methodology to consider the interaction between the different innovation practices, defining an Aggregated Index of potential innovation (APII) (6).

(40) propose the application of Choquet Integral Based Index in order to include interactions between the innovation practices, calling this approach APII (Aggregate Potential Innovation index). In this work, the authors make a review of the 13 practices in order to refine the proposal, performing a new level of aggregation defining a set of six categories grouping these practices according to associate characteristics.

(9) and (16) added two more practices and (6) grouped them in the same six categories defined by (40). This way, they work with 15 practices. For each one of these categories, considering the similarity of the grouped practices, the most important concepts to measure were identified, obtaining 18 concepts, distributed in the cited categories.

(41) incorporates some variants to the Innovation Potential Index (IPI) that consist in identify new weights for the multicriteria analysis to give a more specialized treatment of the index according 
to the firm category. In addition to threshold effects, always having in account the synergy effects of the indicator, have been treated to enhance the indicator (Variable IPI). Also in that work, it is marked that evaluators gain useful insights by considering practices and directly observable phenomena, granting this way a better similarity between the evaluations of different evaluators analyzing the same company, because the achievement of each sub-practice can be proved by facts or documents. It is pointed that sub-practices scoring represents a limitation. A data mining approach is proposed to allow differentiate more innovative companies from the others, and to prove the existence of a synergy effect.

To avoid confusion with the categories of firms according of its level of innovation (19), in the present work the categories of innovation will be called Innovation Criteria. The concepts that conform the categories will be called Innovation Practices. In the following table, the innovation criteria's are presented besides its Innovation Practices:

Table 1: Innovation practices grouped in criteria's with relative weights by criteria and practices

\begin{tabular}{|c|c|}
\hline Innovation Criteria & Innovation Practices \\
\hline \multirow[t]{3}{*}{ Creativity $(17,5 \%)$} & (P01) Use of tools to increase the creativity (4.6\%) \\
\hline & (P02) Integration of the clients and suppliers in the conception process $(5.8 \%)$ \\
\hline & $\begin{array}{l}\text { (P03) Organization, compilation and management of information from the } \\
\text { exterior }(7.2 \%)\end{array}$ \\
\hline \multirow{3}{*}{$\begin{array}{l}\text { New product development } \\
(10,7 \%)\end{array}$} & (P05) Use of tools of help to the conception (4.6\%) \\
\hline & (P05) Existence of a methodology of help to the conception (4.2\%) \\
\hline & (P06) Use of TICs for design (1.9\%) \\
\hline \multirow{2}{*}{$\begin{array}{l}\text { Human Resource } \\
\text { Management }(6,8 \%)\end{array}$} & (P07) Management of competences and the skills of the society $(3.2 \%)$ \\
\hline & (P08) Innovation stimulation (3.6\%) \\
\hline \multirow[t]{4}{*}{ Strategy $(23,2 \%)$} & (P09) Strategy integrated to favor the innovation (1.2\%) \\
\hline & (P10) Network operation (11.8\%) \\
\hline & (P11) Client Importance (6.3\%) \\
\hline & (P12) Financing (3.9\%) \\
\hline \multirow[t]{3}{*}{ Project management $(19,4 \%)$} & (P13) Project administration (1.9\%) \\
\hline & (P14) Management of project briefcase (8.3\%) \\
\hline & (P15) Organization of tasks tied to the Innovation (9.1\%) \\
\hline \multirow{3}{*}{$\begin{array}{l}\text { Capitalization of ideas and } \\
\text { concepts }(22,4 \%)\end{array}$} & (P16) Improvement Continued of the innovation process (7.6\%) \\
\hline & (P17) Politics of Management of the intellectual property (6.5\%) \\
\hline & (P18) Knowledge Capitalization (8.3\%) \\
\hline
\end{tabular}

Some authors propose auditing technological processes, identifying core processes and enabling processes. (11) in their works have used technological innovation capabilities (TICs) as for example R\&D, Manufacturing and Strategic planning capability to perform the impact on firm's competitive performance. The R\&D and patents criteria were gathered, which presents many disadvantages as it have seen previously. Surveys applied to the companies are also used as another method to gather direct and subjective information (10). In Argentina, (12) have defined an indicator of innovation capacity conformed by five main criteria: Human resources capacitation, quality orientation, interaction with other agents, engineering and technicians participating in innovation activities.

\subsection{Argentinian sample}

The Argentine sample has 25 firms related to construction and 9 firms related to the food industry. Of these 34 firms, 20 are older than 15 years and only 6 are younger than 5 years. 3 firms have more than 100 employees, 3 between 50 and 100 and 22 between 10 and 49 and the rest 6 , less than 6 employees. In the panel, 11 firms manifest growths of more than $30 \%, 16$ firms manifest a growth at most of $30 \%, 6$ firms manifest no growth and only one manifest descending sales level. 9 firms can be considered Medium-tech in the complexity of technology implementation, and 
25 low tech firms (42). From the current panel, 18 of the 34 firms are family managed.

\subsection{French Sample}

The French panel consists in 32 companies; all of them are located in Lorraine's region. From this total, 9 firms have less than 10 years operating and only 6 have more than 30 years. The average number of employees is of 22 for company; being 143 the greatest number of employees and only 3 the minor. The level of sales of these companies is very varied and ranges from 200.000 to 12.000.000 euros in 2009. The companies belong to different sectors; most of them belong to carpentry sector, while the rest divides in five activity sectors in relatively similar quantities (construction, food industry, metalwork, wood and unspecified where several sectors are represented).

\subsection{Maturity grid}

To collect the data, in the present work a maturity grid approach was used. To support management and enable improvement, performance assessments are commonly used. One way of assessing organizational capabilities is by means of maturity grids. Dealing with hundreds of requirements can be frustrating. Most maturity grids apply to companies in any industry and do not specify what a particular process should look like. They identify the characteristics that any process and every enterprise should have in order to design and deploy high-performance processes. Typically structured around a grid in the cells it provides descriptive text for the characteristic traits of performance at each level, also known as a "behaviorally anchored scale" (43).

Maturity grids describes, in few phrases, the characteristic behavior exhibited by a firm at a number of levels of 'maturity', for each of several key process areas. Maturity grids are a way of describing the characteristics of an activity at a number of different levels of performance. For repetitive activities, it is likely the existence of defined process, to ensure consistency of approach and outcome (44). To construct and adequate grid, a series of step must to be done: 1) Specify Audience, 2) Define Aim, 3) Clarify Scope and 4) Select Maturity Levels (Rating Scale)
Then, it is necessary to formulate Cell Text: Intersection of Process Areas and Maturity Levels): It is one of the most important steps. Process characteristics need to be described at each level of maturity. A mechanism to formulate the cell text as rating scale consist in identify extreme ends of the scale, i.e., best and worst practices, and then, to determine characteristics of all the stages in between. To set the administration mechanism is necessary to determinate if it will have focus on process (raising awareness): Individual scores are taken as prompts for a discussion and identification of steps for improvement, or focus on end results (benchmarking) where the scores are collated to give an overall assessment of the capability and an overall maturity level. For the evaluation stage, a previous validation is recommended (43).

\section{RESULTS}

\subsection{Innovation Potential Index}

In the evaluation done, it was possible to detect that in the French panel, the $31 \%$ of firms belong to the reactive class ( 10 firms). The $62 \%$ belongs to passive class (20 firms) and the 7\% (2 firms) belong to proactive class. In the Argentinian panel, also the $41 \%$ belongs to reactive class (14 firms) and $56 \%$ to the passive class (19 firms). One firm belongs to Preactive class (3\%).

It was found that the Innovation Potential Index (IPI) have a similar media en both panels, 0.266 in argentine panel and 0.262 in the French panel, with differences no statistically significant.

The second analysis done was the mean of the IPI differentiated in classes. In this case, the media for reactive firms was 0.375 and 0.38 respectively to Argentinian and French panel, with no statistically significant differences. In the case of passive firms, the medias were 0.201 (Argentina) and 0.179 (France), also with no statistically significance.

\subsection{Criteria comparison}

About the six criteria that compose the index, a comparison have been made. The results to all the firms are shown in the Figure 1. 


\section{Complete sample Comparisson France-Argentine}

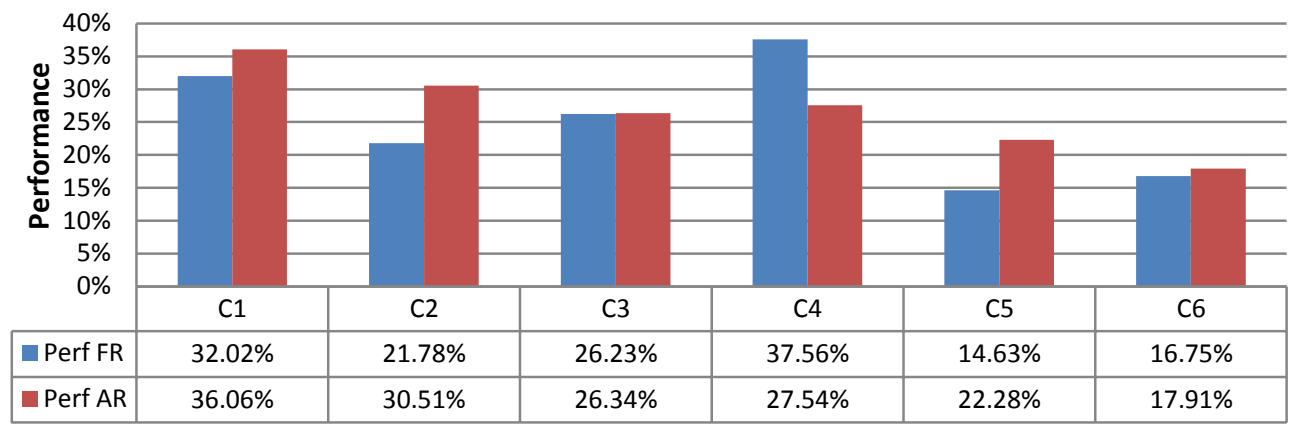

Figure. 1: Criteria comparison for all firms in two samples

The same analysis have been made for the reactive (Fig. 2) and passive class (Fig. 3).

\section{Reactives - Comparisson France-Argentine}

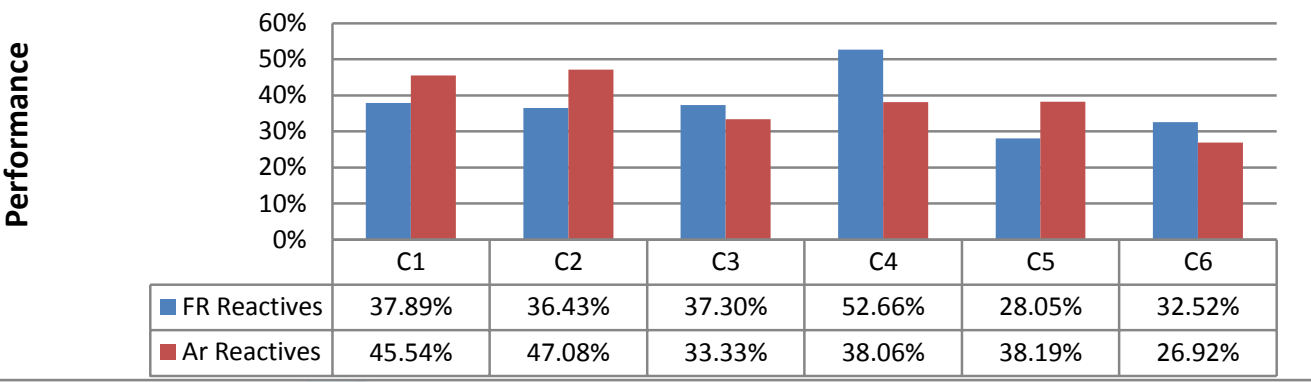

Figure 2: Criteria comparison for reactive class

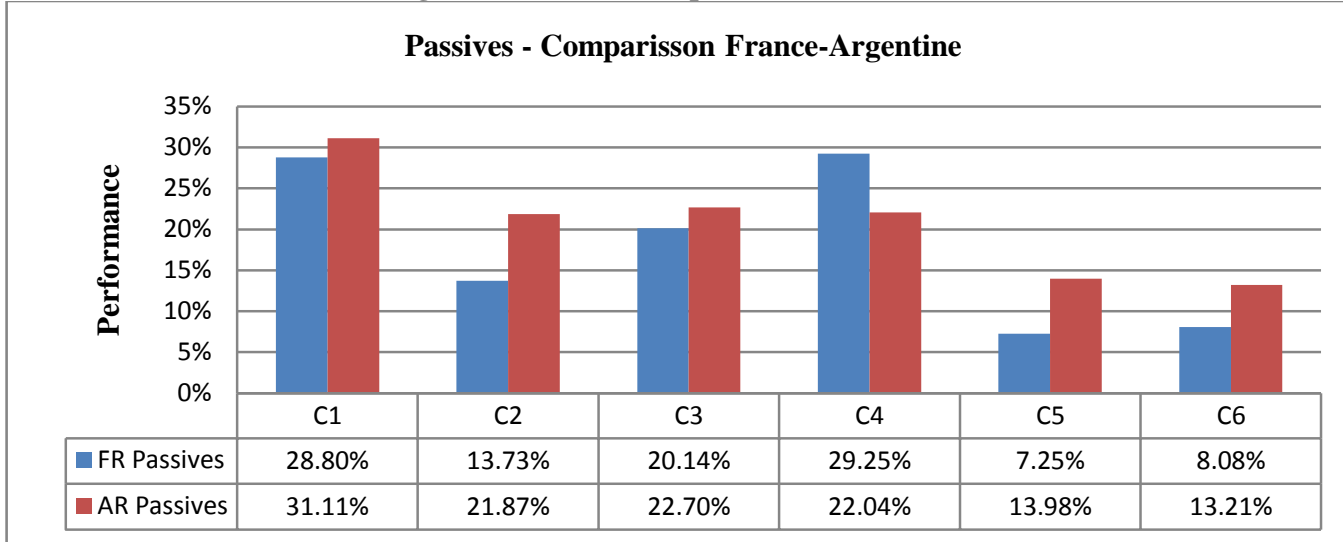

Figure 3: Criteria comparison for reactive class 
The differences that results statistically significant with $\mathrm{P}>95 \%$ are for the general sample: $\mathrm{C} 4$ and C5 coinciding with passive class; for the reactive class: $\mathrm{C} 1$ and $\mathrm{C} 4$.

\subsection{Criteria contribution to Innovation Potential Index}

An analysis of the contribution of the criteria to the overall index was done. This is considered important because the indicators that are calculated by a multicriteria methodology have compensatory effects that are not visible in the overall indicator. This way, analyzing each criterion it was possible to observe that there are differences in the most contributive criteria in both panels. While C4 (Strategy) is the most contributive in the French panel and in the reactive Argentinian firms, in the Argentinian passive class is the second most contributive. The $\mathrm{C} 1$ (Creativity) is in this case the most important.

Something similar arrives with the less contributive criteria. The third criteria C3 (Human Resources) is the less contributive to the complete sample with exception of the French passive group, in which the fifth (Innovation project management) is the less developed.

Besides the contribution to the IPI indicator, it results interesting to know the development of each criterion independently of the index. In the following figures (Figure 4 to Figure 9), a contribution and performance level comparison is shown for each criterion, in each class and lastly for the complete sample.

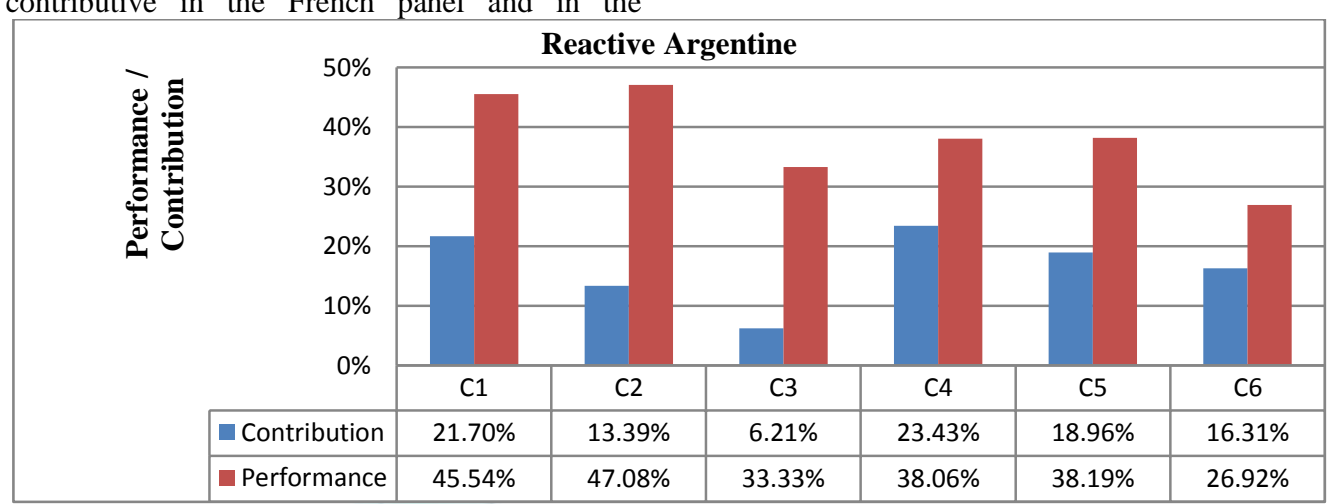

Figure 4: Criteria performance and contribution to the IPI for Reactive Argentinean firms

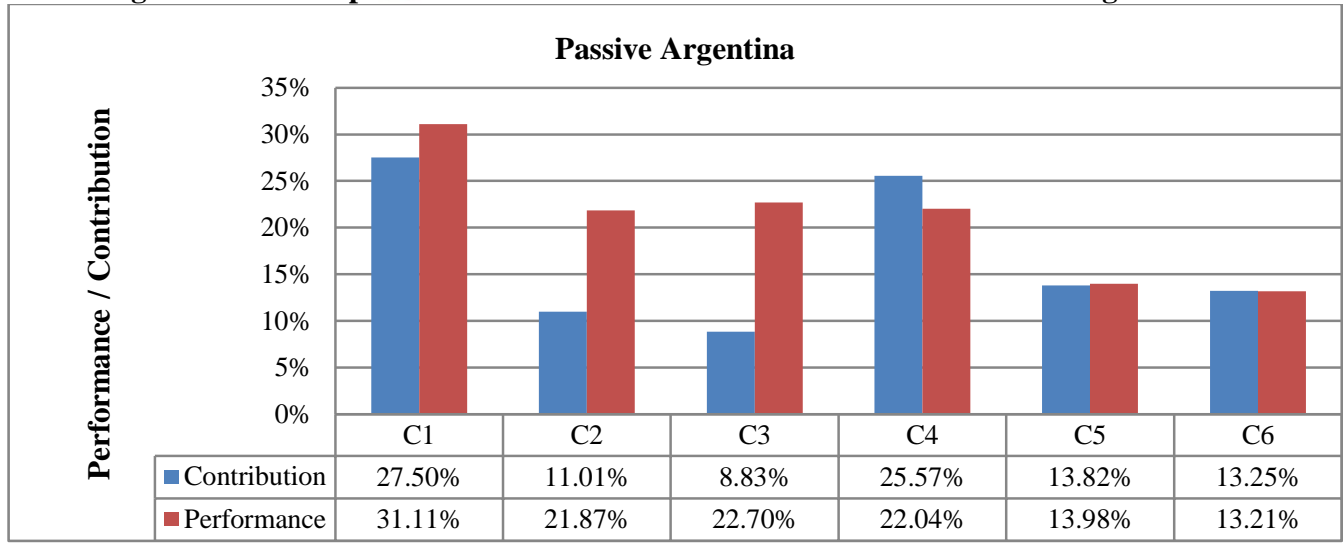

Figure 5: Criteria performance and contribution to the IPI for Passive Argentinean firms 


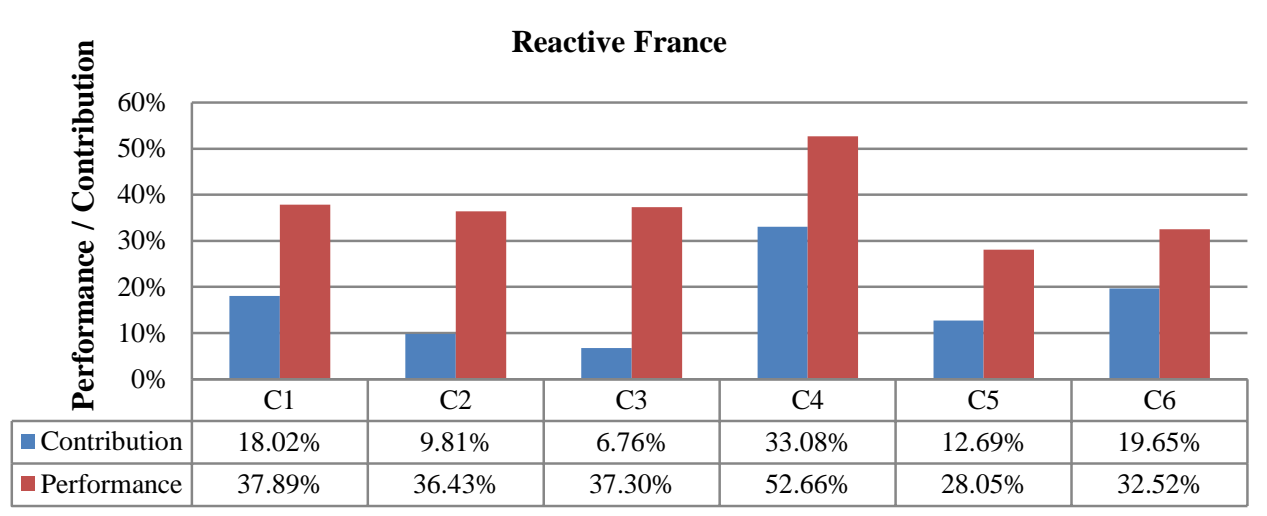

Figure 6: Criteria performance and contribution to the IPI for Reactive French firms

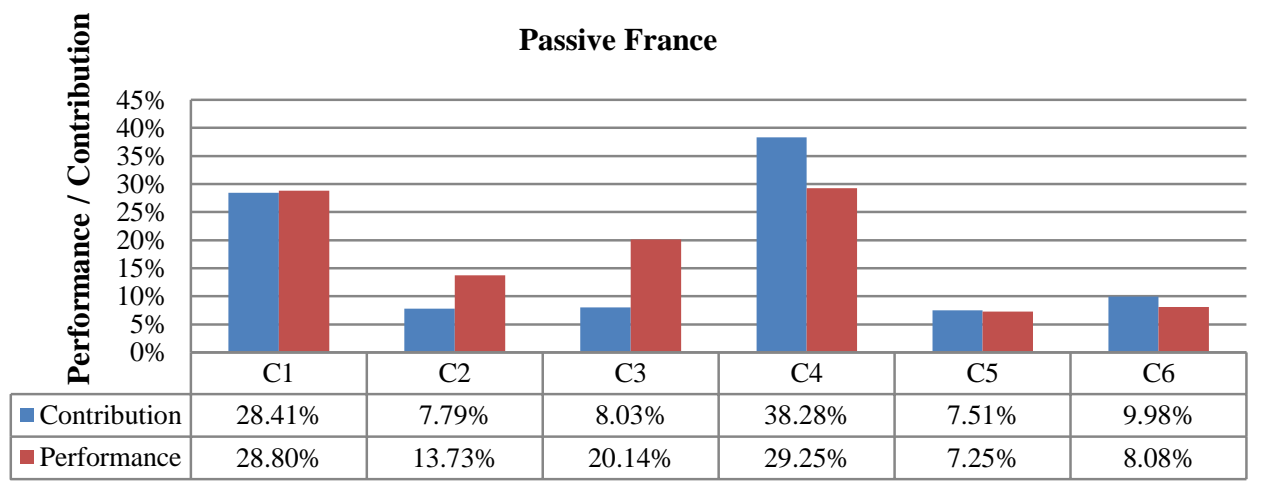

Figure 7: Criteria performance and contribution to the IPI for Passives French firms

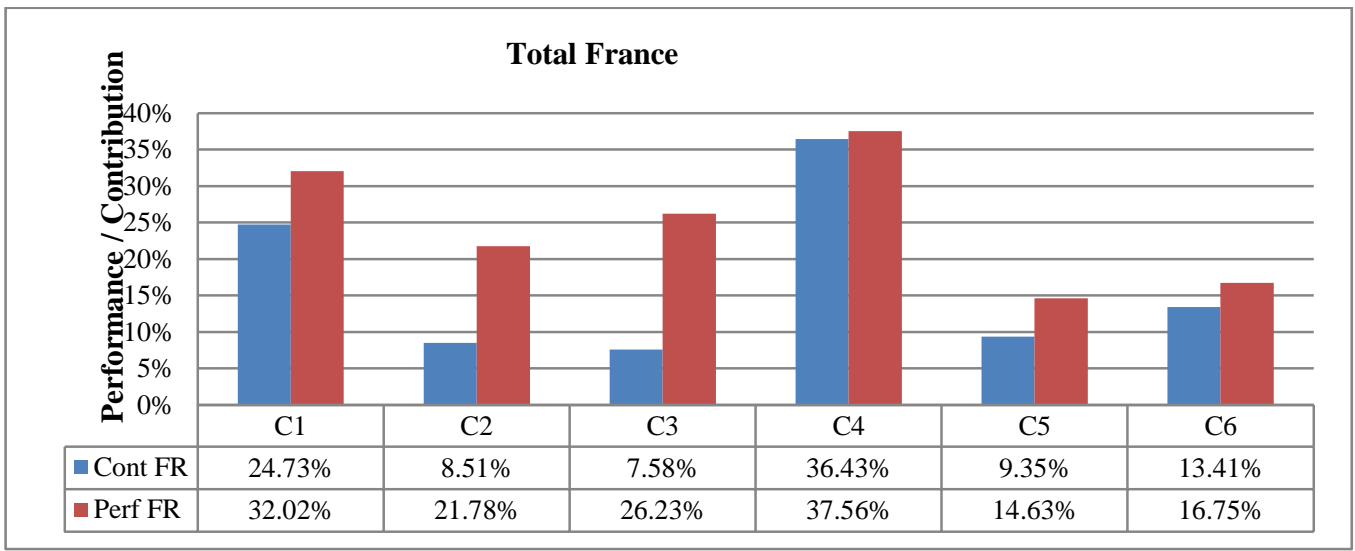

Figure 8: Criteria performance and contribution to the IPI for all French firms 


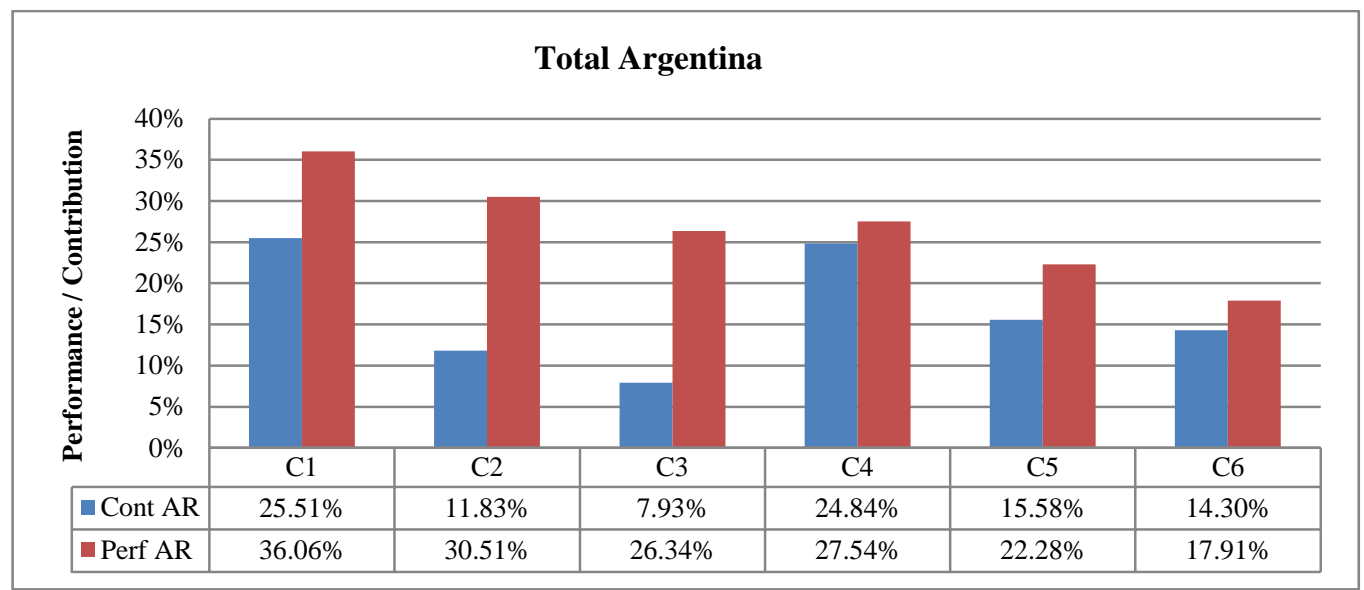

Figure 9: Criteria performance and contribution to the IPI for all Argentinean firms

\subsection{Practices performance \\ comparison}

Next to the criteria analysis, a practices comparison has been made. Results are shown in Figures 10 and Figure 11. It is possible to note that in the passive class the difference tends to be bigger than in the reactive class. In practices P01, P10, P14 and P18 differences persist along the two classes. The practice $18^{\text {th }}$, about knowledge capitalization, has better performance in French reactive firms but the opposite occurs in the passive class.

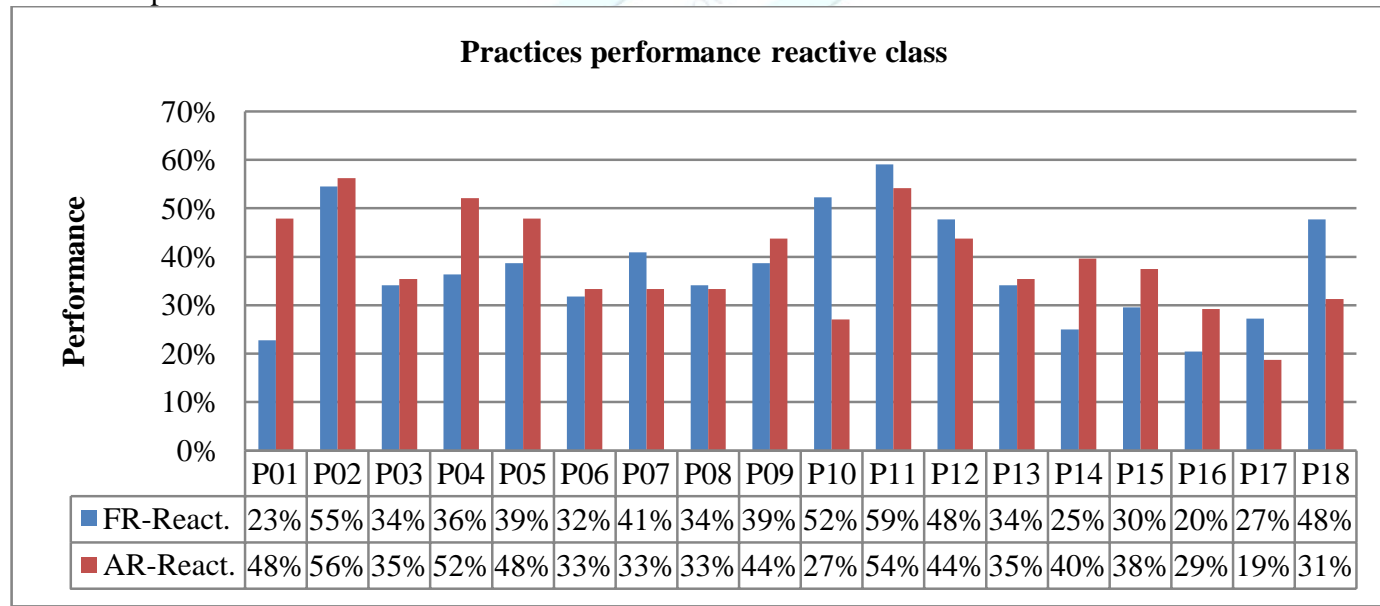

Figure 9: Practice performance comparison for reactive class 


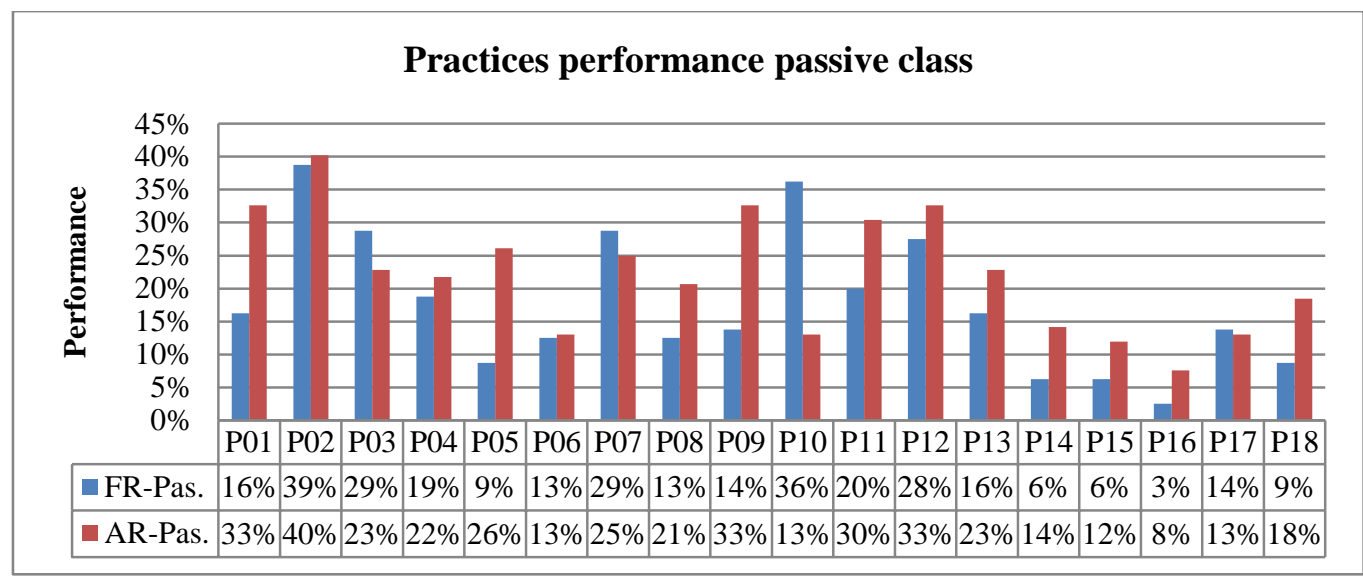

Figure 10: Practice performance comparison for passive class

The differences that results statistically significant with $\mathrm{P}>95 \%$ are for the general sample: $\mathrm{P} 01, \mathrm{P} 05$, P07, P09 and P014. P15 and P16 results statistically significant with $\mathrm{P}>90 \%$; for the Reactive class: P01, P04, P05, P07, P10, P14 and P18 (P>95\%); lastly for the passive class: P01,
P05, P08, P09, P11, P12, P13, P18 (with P>95\%) and $\mathrm{P} 15, \mathrm{P} 16(\mathrm{P}>90 \%)$

\subsection{Relatives differences}

It is interesting to visualize the relatives differences form the average about the criteria's performance. In the Figure 11, it is possible to see this difference.

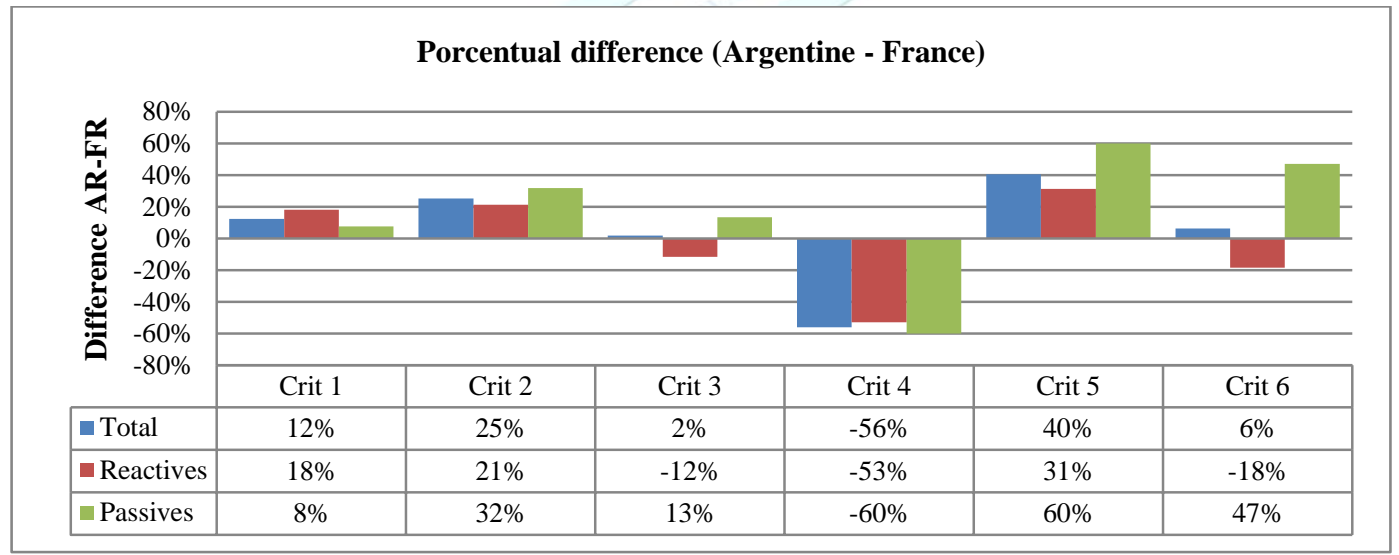

Figure 11: Relative differences in criteria by classes

As it is possible to observe, the biggest differences appear in Strategy and Project management criteria (C4 and C5 respectively). French firms perform better in Strategy and Argentinian ones in Project management. A particular phenomenon occurs in criterias C3 and C6, where Reactive French firms perform better and the opposite occurs in Passive group.

\section{CONCLUSIONS}

\subsection{IPI composition for both groups}

It is interesting to know that there are not significant differences between the two samples about the overall IPI. This occurs in the general sample and in the two classes founded. 
The average differences in criteria performance doesn't go over the $20 \%$, so that implies that the firms, independently of particular discrepancies, perform similar in innovation. That confirms that the fact to belonging to SME groups present a strong importance in innovation performance.

Strategy criteria results the most contributive for the complete sample and also for both class in French panel and reactive class in Argentinean panel. In passive Argentinean group, the first criteria (creativity) are the most contributive. In reactive Argentinean panel, C2 about conception activities is the better performed criteria; nevertheless it is not the most contributive.

The third criterion is poorly developed in all the sample and results to be the less contributive. But, in absolute terms is not the less developed. Its average performance is about $26 \%$ in two samples. This can be due the fact to belonging to low-tech SME sector. This results are aligned whit the founding of (12) and (21). The criteria about project management is the less developed in the French panel perhaps due the spread of the sample sectors. The criteria C6 that deals with Knowledge management is the worst in Argentinean sample with scarcely $14 \%$ of development.

Looking at the individual criteria, in the complete sample a significant differences is found in the fourth criteria (Strategy favoring innovation) favoring the French firms. This result is not surprising because is aligned with the present and recent history of the economic situation in two countries. While France is a country with strong economic policies, and belonging to European Economy Union (CE), Argentina is characterized in the last 30 years by a succession of economic and social crisis (45). Other reason that influences the Strategy criteria in Argentinean SMEs is the business to business orientation (33). This way SMEs, that generally are big firms providers, are mostly "pull" responsive. The client big firm defines strategy and the SME, generally follows it. The same phenomena persist through the classes, given an important hint about the situation specified above. In the fifth criteria, about the management of innovation projects, appears a difference favoring Argentinian SMEs, statistically significant in the overall sample and in passive class. Possibly, this phenomenon could be based in the high proportion of firms belonging to construction sector that is highly dependent of project management activities. The first criteria (Creativity) show a better performance in Argentinian SMEs, especially in reactive firms. This result is not aligned with (46) that position in the Global Creativity Index (GCI), France in the 15th place and Argentina in the 33th place. Nevertheless, this index is not related directly with SMEs creativity. It is possible that this situation configures another consequence of the concentration of construction industry in the Argentinean panel.

\subsection{Practices}

About the 18 innovation practices, the results found indicates that French firms performs better in network operation, maybe other consequence of the short time visibility of the Argentinian firms, due the always present instability. Firms avoid efforts to long-term and contracts and networks consolidation. This practice represents almost $12 \%$ of the overall index and about $50 \%$ of Strategy criteria C4. This result coincides with (45) about the weakness of links with the regional industrial web. He assigns that to constants change in its offer and target markets. In the opposite, France firms via the competitiveness clusters intend to build new coordination facilities based on the operational interconnectivity among territorial development, innovation and the industrial sector (47).

About the Innovation project management criteria, Argentinian firms perform better in Organization the tasks for innovation and in Project briefcase, criteria's that together brings $17 \%$ of the overall index and $90 \%$ of project management criteria C5. This result aligns with findings in (12) about the dispersion in the Argentinean SMEs offer due the constants change that force to evade the concentration risks. Furthermore, these results agree with (45) about the lack of concentration strategy that prevent increase knowledge via specialization.

About the Knowledge capitalization, in overall sample, both panels perform similar. Nevertheless, French reactive firms perform better than Argentinian and the opposite arrives with the passive group. To the continuous improvement of 
innovation process, Argentinian sample perform better in average, but there is an important difference favoring French passive panel. About using tools for conception, Argentinian panel manifest that use computers to make the plans and several times use prototype, meanwhile the French panel manifest only make the plans in computer software. This could arrive because the costs of computer software are rarely paid in Argentina due the informality about CAD licenses utilization.

In the case of the practice of using tools for creativity, Argentinian firms perform better along the entire panel. Similar situation arrives with the existence of a methodology to help design. In using TICs for design, both panels have very low values. This can be viewed as an opportunity to enhance next to the utilization of tools for conception.

\subsection{Overall conclusions}

Innovation management is very informal and poorly developed in low-tech industrial SMEs. This conclusion appears to be valid to a wide variety of sectors. French firms and Argentinian firms perform relatively similar and low performing. This conclusion may change if others regions are selected for the present analysis. The Norwest area in Argentina is poorly developed and the Lorraine region is not comparable to the Paris Metropolitan area regarding to industrial development. Such considerations may be considered to further research if a generalization of result is necessary.

\section{6.}

\section{IMPLICATIONS}

Measuring the Innovation Potential Index is necessary for managers to get into a continuous improvement circle. Benchmarking needs this stage to be complete. Nevertheless, in an absolute measurement it is no possible to determinate the state of the firm comparing with others. Benchmark this results with others sample belonging to other region brings rich management information.

It is a fact that different environments make relative the comparison, but via the different levels of development found in criteria's, it is possible to determine areas of enhancement.
A more rigorous adjustment must to be done in order to have a useful indicator. The comparison between two different countries may be a very important initial step, Moreover; adjustments about industrial sectors and operatives regions may be useful in further researches.

\section{DISCUSSION}

The present analysis has shown that SMEs perform similar about the IPI in both panels with some differences about the index composition. Some of these differences were expected due the different operatives environment in which the firms development itself. Other differences were unexpected and it would be interesting to investigate about its possible causes. It is possible that the samples were not enough heterogeneous to conform a really representative sample. In the case of Argentinian sample, almost all the panel belongs to two sectors: Food and construction. The majority of the firms in two panels belong to the low-tech category.

The general low intensity detected in some criteria suggests that the indicators could be adjusted to the general level existent in industrial SMEs. If a random sample is assumed, it is almost impossible that no practice get over the $50 \%$ in performance. The indicator may be exigent in that sense or it is possible that relatives measures will be more useful.

Other possible adjustment could be separate the panels in low-tech and high-tech SMEs, due the different importance of innovation inherent to the belonging category. Same consideration is valid across the industrial sectors.

It is possible that several weights must to be revised, like the weight of network participation. In (23) there are results that are opposite to the importance given.

A question is presented: What criteria is the most important? What practice contributes more to the firm success? It is clear that a relationship between the criteria performance and firm performance in general is needed.

\section{REFRENCES}

[1]. A study of the relationship between competitiveness and technological innovation 
capability based on DEA models. Guan, Jian Cheng, Richard , C.M. y Kam Mok, Yam Chiu . 2006, European Journal of Operational Research 170, págs. 971-986.

[2]. Boly, Vincent. Ingénierie de l'innovation organisation et méthodologies des entreprises innovantes. Paris : Hermes Science Publications, 2008.

[3]. Value Innovation: The strategic Logic of high growth. Kim, Chan W. y Mauborgne, Renée. 1997, Harvard Business review, págs. 102-112.

[4]. OECD Science, Technology and Industry Outlook. OECD. s.l. : OECD Publishing, 2010. OECD Science, Technology and Industry Outlook.

[5]. Development of a technical innovation audit. Chiesa, V. , Coughlan, P. y Voss, C.A. 1996, Journal of Product Innovation Management, págs. 105-136.

[6]. Enhancing firms innovation capabilities through the innovation metrics. González, Javier, y otros, y otros. 2010.

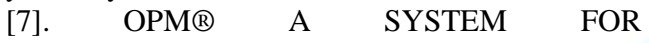
ORGANISATIONAL PERFORMANCE MEASURENMENT. Chennell, A.F., Dransfield, S. B. y Field , J. B. . 2000, University of Cambridge, págs. 19-21.

[8]. Report, Benchmarking Innovation: A short. Radnor, Zoe y Robinson, Judith. 2000, CREATIVITY AND INNOVATION MANAGEMENT, págs. 3-13.

[9]. APPLICATION OF AN OUTRANKINGBASED SORTING METHOD TO IMPROVE THE CLASS IDENTIFICATION OF INNOVATIVE FIRMS. Camargo, Mauricio, y otros, y otros. s.l. : International Association for Management of Technology, 2009. IAMOT 2009. [10]. Performance measurement systems in SMEs: A review for a research agenda. Garengo, Patricia, Biazzo, Stefano y Bitit, Umit S. 2005, International Journal of Management Reviews , págs. Volume 7 Issue 1 pp. 25-47.

[11]. Evaluating firm technological innovation capability under uncertainty. Wang, C-H, Lu, I-Y y Chen, C-B. 2008, Technovation 28, págs. 349363.

[12]. La capacidad innovativa y el fortalecimiento de la competitividad de las firmas: El caso de las PyMEs exportadoras argentinas. Yoguel, Gabriel and Boscherini, Fabio. Buenos Aires : s.n., 1996. Comisión Económica para América Latina y el Caribe (CEPAL).

[13]. Attaining world-class R\&D by benchmarking buyer-supplier relationships. Hurmelinna, Pia , y otros, y otros. 2002, International Journal of Production Economics , págs. 39-47.

[14]. Zairi , Mohamed y Jarrar, Yasar F. . Future Trends in Benchmarking for Competitive Advantage: A Global Survey. Bradford : European centre of best practices management, 2010.

[15]. A framework for measuring logistics performance in the wine industry. Garcia, Fernanda, y otros, y otros. 2012, International Journal of Production Economics, págs. 284-298. [16]. Linkages between manufacturing strategy, benchmarking, performancemeasurement and business process reengineering. Herzog, Natasa Vujica, Tonchia, Stefano y Polajnar, Andrej. 2009, Computers \& Industrial Engineering, págs. 963-975.

[17]. Innovation Management Practices, Strategic Adaptation, and Business Results: Evidence from the Electronics Industry. Sánchez, Alba, y otros, y otros. 2011, Journal of Technology management and innovation, págs. 14-39.

[18]. ASSIELOU, Guilloume. METROLOGIE DES PROCESSUS D'INNOVATION - These doctoral. Nancy : INPL, 2008.

[19]. An audit of technological innovation capabilities in chinese firms: some empirical findings in Beijing, China. Yam, Richard C.M. , y otros, y otros. 2004, Research Police - Elsevier, págs. 1123-1140.

[20]. Comparison of multicriteria analysis techniques to improve the innovation process measurement. Morel, Laure y Camargo, Mauricio. Beijing : s.n., 2006. IAMOT 2006.

[21]. Godet, M. Manuel de prospective stratégique. Tome 2. L'art et la méthode. Paris, France : Dunod, 1997.

[22]. OECD. The OSLO manual: Measurenment of scientific and technological activities. Oslo : Organisation for Economic Co-operation and Development, 1997.

[23]. Small and medium enterprise innovation in region of Antofagasta - Chile. Roman, Gianni y 
Atienza, Miguel . 2005, Ciencia y Tecnología Administrativa.

[24]. Desarrollo de ventajas competitivas: pymes exportadoras exitosas en Argentina, Chile y Colombia. Milesi , Dario, y otros, y otros. 2007, CEPAL, pág. pp 25 a 43.

[25]. Fundación Observatorio Pymes. Informe especial: Competitividad empresarial, desarrollo organizativo y gestión comercial de las PyME industriales. Buenos Aires : Fundación Observatorio Pymes, 2010.

[26]. Is innovation always beneficial? A metaanalysis of the relationship between innovation and performance in SMEs. Rosenbusch , Nina, Brinckmann, Jan y Bausch, Andreas . 2011, Journal of Business Venturing, págs. Vol 26 pp 441-457.

[27]. Innovation and Business Performance: Small Entrepreneurial Firms in the UK and the EU. Hughes, Alan. Cambridge : University of Cambridge, 2001. Judge Institute of Management Studies and Centre for Business Research. págs. pp 65-69.

[28]. Trott, Paul. Innovation management and new product development 3rd ed. Edinburgh : Pearson Education Limited, 2005.

[29]. The new SME definition: User guide and model declaration. European Community. s.l. : ENTERPRISE AND INDUSTRY PUBLICATION, 2003, Journal of the European Union, págs. L 124, p. 36.

[30]. Alternative Knowledge Strategies, Competitive Environment, and Organizational Performance in Small Manufacturing Firms. Bierly III, Paul E. y Daly, Paula S. . 2007, Entrepreneurship Theory and Practice, págs. Volume 31, Issue 4,.

[31]. In search of the drivers of high growth in manufacturing SMEs. O'Regan , Nicholas, Ghobadian , Abby y Gallear, David. 2006, Tecnovation - Elsevier, págs. 30-41.

[32]. Salles, Marysse. Stratégies des PME el intelligence économique. s.l. : ECONOMICA, 2003.

[33]. Meunier, Alain. PME: Les stretegiés de succes. Paris : Dunod, 2007.

[34]. Yoguel, Gabriel y Moori-Koenig, Virginia.

Los problemas del entorno de negocios.
Desarrollo competitivo de las PyMEs Argentinas. Buenos Aires : Fundes, 2000.

[35]. Managing funding for innovative European SMEs. Taplin, Ruth. 2006, Engineering Management, págs. 18-23.

[36]. Farinelli, Sergio y Piñero, Julio. Sistemas locales de innovación: Las empresas Pymes matalúrgicas de Tandil. Tandil : Universidad Nacional del Centro, 2005.

[37]. Bruera, Ignacio. Las PyMES en la economía argentina. Presente, perspectivas y condiciones necesarias para su crecimiento y rentabilidad. s.l. : INSECAP - UCES, 2011.

[38]. PME-Lorraine. TPE et PME en Lorraine : des quantités non négligeables. Nancy : PMELorraine, 2004.

[39]. An integrated marketing capability benchmarking approach to dealer performance through parametric and nonparametric analyses. Akdeniza, M. Billur, Tracy, Gonzalez-Padronb y Roger J. 2010, Industrial Marketing Management, págs. 150-160.

[40]. European Centre for Total Quality Management. Benchmarking: a global survey. Bradford: UK : ECTQM Report, 2000.

[41]. Morel, Laure, Camargo, Mauricio y Boly, Vincent. Mesure de las Capacites a Innover PMI/PME - -. Le grand Livre de 1'Economie PME. Paris : Gualino, 2012, págs. 123-145.

[42]. A methodology to measure the innovation processes capacity in enterprises. Corona Armenta, Jose, Morel, Laure y Boly, Vincent. Viena : s.n., 2005. IAMOT 14th International Conference on Management of Technology.

[43]. Integrating Product Innovation Degree and Technological Strategy. Use of Constrained multicriteria optimisation for a Polymerisation Process. Morel, Laure, Fontenix, C y Camargo , Mauricio. 2007. 11ème Congrès de la Société Française de Génie des Procédés.

[44]. A new methodology based on Kano model for the evaluation of a new product acceptability during the front-end phases. Ben Rejeb, H, Boly, Vincent y Morel-Guimaraes, Laure. Turku : s.n., 2008. International Computer Software and Applications Conference. págs. 619-624.

[45]. Marteau, Silvia. La Actuación Estratégica de las Pequeñas y Medianas Empresas. La Plata : s.n., 2002. 
[46]. Assessing Organizational Capabilities: Reviewing and Guiding the Development of Maturity Grids. Maier, Anja M. , Moultrie, James y Clarkso, P. John . s.l. : IEEE TRANSACTIONS ON ENGINEERING MANAGEMENT, VOL. 59, NO. 1, FEBRUARY 2012, 2012, VOL. 59, NO. 1. [47]. Development of a structured approach to assessing practice in product development collaborations. Farrukh, C., Fraser, P y Gregory,
M. 2003, Proc. Instn Mech. Engrs Vol. 217 Part B: J. Engineering Manufacture, págs. pp 11311144.

[48]. Martin Prosperity Institute. Creativity and Prosperity: The 2010 Global Creativity Index. Toronto - Canada : University of Toronto, 2011. [49]. Villa, Agostino y Antonelli, Dario. A Road Map to the development of European SME Networks . Torino, Italia : Springer, 2009. 